\title{
Changing ethics rules land Spanish stem cell scientist in hot water
}

The Spanish health ministry is considering legal action against one of the country's top stem cell scientists, saying he conducted research without proper authorization.

But the researcher, Carlos Simón, and the local government in Valencia, where he works, say the ๖ ministry's actions are politically motivated.

Simón, scientific director of the Valencian Infertility Institute, created two undifferentiated embryonic stem cell lines in March 2004. Two months later, along with former health minister Ana Pastor and Vicente Rambla, head of Valencia's health department, he publicly presented the lines.

He and his colleagues also published a full characterization of the lines in January (Fertil. Steril. 83,246-249;2005). He now says he has succeeded in differentiating them into cells resembling those in the pancreas, heart and brain.

But in late September, the central health ministry announced that the cell lines could no longer be used for research. Roberto Rodríguez, a spokesperson for the ministry, says Simón did not have informed consent from parents for the 40 embryos he used for his research, nor did he have formal approval from the ministry. "That is a clear violation of the current rules," Rodríguez says.
Simón says his stem cell lines were developed during the previous administration, when a different law on assisted human reproduction was effective. That law, approved in November 2003, allowed research on stem cells from spare embryos donated before it took effect.

After the Socialist Party came to power in April 2004 it enacted a new, less restrictive, law that allows the use of embryos for research purposes at any time and set up informed-consent procedures. In November 2004, the new government also created a health ministry committee to evaluate research on human embryos.

In January 2005, Simón requested formal approval for his projects from this new committee and obtained informed consent from parents of the 40 source embryos. But it was too late. The ministry says the informed consents do not apply because they were signed after the embryos were already used.

But the ministry granted approval to similar projects by Catalan and Andalusian scientists, where the regional governments are socialist, notes Rambla.

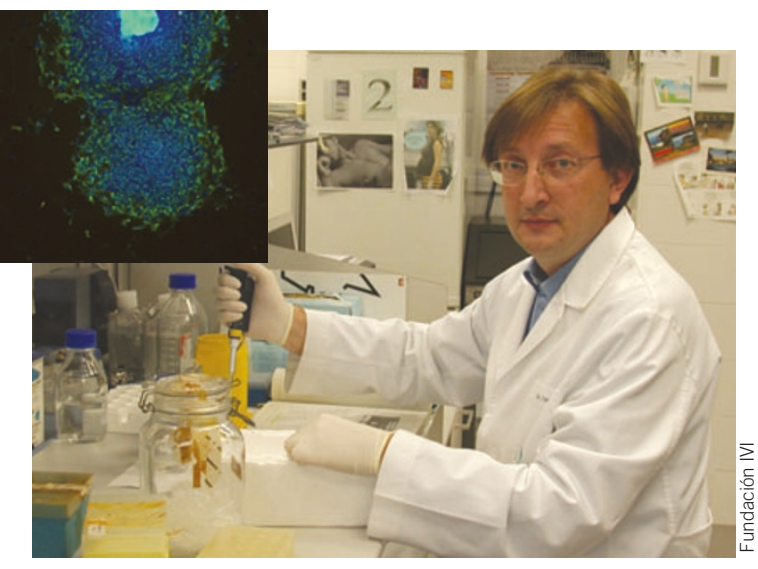

Scrambled eggs: Spanish scientist Carlos Simón is under fire for developing stem cells without proper consent.

"Our research is halted because of political motives," adds Simón. "If we stick to scientific, legal, ethical and rational parameters, we are unable to understand the decision."

The ministry is contemplating penalizing the scientists for violating the law. In the meantime, Simón-with the support of the Valencian government-is continuing work on his cell lines.

Xavier Bosch, Barcelona

\section{Blood pressure vaccine shot down by safety concerns}

A new vaccine for high blood pressure has sparked a debate on the long-term safety of the approach.

Vaccines for hypertension would solve one of the most vexing problems facing doctors: individuals who don't take their drugs properly. Promising candidates periodically emerge but remain dogged by concerns about unintended immune responses.

In the latest venture, Swiss company Cytos Biotechnology is proposing a vaccine that targets the renin-angiotensin system, which is key to the regulation of blood pressure. The researchers reported at a conference in November that a peptide vaccine derived from angiotensin II, the hormone that causes arteries and veins to constrict, produces an antibody response in humans. In earlier rat studies, the same response translated to a drop in blood pressure, the researchers say.

High blood pressure is a pervasive problem, affecting one in three Americans and nearly 1 billion people worldwide. There is a growing list of effective drugs, including those that block angiotensin's effects, diuretics and calcium-channel blockers. Still, hypertension remains a problem, in part because many of those affected do not take the daily drugs regularly.

A vaccine that is given only a few times a year might solve that problem, says Martin Bachmann, chief scientific officer at Cytos. The Cytos vaccine uses a noninfectious viruslike particle to carry the immunogen. The company is also testing this carrier in clinical trials for vaccines against Alzheimer disease, obesity, nicotine addiction and allergies.

Experts say the company's data are promising but preliminary. Scientists have experimented with vaccines against the reninangiotensin system for more than 50 years, notes Jean-Baptiste Michel, director of hematology at the Xavier Bichat Hospital in Paris.

Last year, researchers at Cambridge University and UK-based Protherics tested a high blood pressure vaccine that targeted angiotensin I, a precursor to the more powerful angiotensin II. The approach generated antibodies but did not significantly modify blood pressure, Michel says.

Merely generating antibodies does not guarantee that those antibodies can bind and inhibit angiotensin II in tissues - a necessary but risky step, he says. In the early 1990s,
Michel himself developed a renin vaccine that blocked the generation of angiotensin in both plasma and tissues. The vaccine induced antibodies in marmosets and reduced the animals' blood pressure. But both primates and rats developed autoimmune disease. Based on his data, Michel says it may not be possible to block angiotensin without targeting it in tissues, which he predicts would inevitably trigger an autoimmune reaction.

Others say a sustained immune response might also have other long-ranging effects.

"High blood pressure is a long-term issue," says Walinjom Muna, chief of cardiology at the University of Yaoundé in Cameroon. "What are the long-term consequences of permanent receptor blockade in humans or closely related species?"

The Cytos studies do not yet have data to respond to those concerns, says Bachmann, but a phase 1 study showed that antibody levels dropped close to background levels within a few months. There have also been no signs of kidney disease or elevated levels of immune complexes, he adds.

Tinker Ready, Boston 